\title{
Protective effect of deoxynucleotide triphosphates on DNA damage in different mammalian cells exposed to $\gamma$-radiation
}

\author{
Elmaghraby, $\mathbf{T}$
}

National Center for Radiation Research and Technology,Egypt.

\begin{abstract}
DNA is generally considered to be the most critical cellular target when considering the lethal, carcinogenic and mutagenic effects of drugs, radiation and environmental chemicals. So the study aim to the determination the damaging effect of $\gamma$-radiation on DNA and the protective effect of deoxynucleotide triphosphates (dNTPs). The study includes three cell types, lymphocytes, kidney cells of African gree monkey (Vero) and hepatocellular carcinoma of human (HePG2) exposed to 1-5 Gy of $\gamma$-radiation and by using fluorometric analysis of DNA unwinding (FADU) method, DNA damage was measured after radiation. The cells were divided into two groups:

The first received $5 \times 10^{-5}$ dNTPs from 0-30 minutes after radiation, while the second group was not supplemented with deoxynucleotides. Clonogenic survival for vero and HePG2 cell lines was measured. The results revealed that the increase of irradiation dose precipitates an increase of DNA strand breaks. The slope curve of initial DNA damage and mean inactivation dose ( $\bar{D}$ ) differ between vero and HepG2 cell line by a factor of up 3.5 and 2, respectively.

dNTPs have clear ameliorating effect on DNA damage. FADU method can play an important role in the choice of a suitable treatment (radiation or drugs) and its dosage according to measurement of DNA damages in selective malignant tissues. Moreover, using dNTPs mixture can reduce the side effect of these treatment especially after experimentally on live mammals (mice) .
\end{abstract}

\section{Introduction:}

DNA is generally considered to be the most critical cellular target when considering the lethal, carcinogenic and mutagenic efects of drugs radiation and environmental chemicals. These agents may damage DNA by altering bases or disrupting the sugar-phosphate backbone. It is generally accepted that cell death induced by ionizing irradiation is due to DNA double strand breaks (Steel et al., 1989). The molecular mechanisms that control variations in radiation induced DNA damage between cell types are not understood. Both the initial DNA damage and the residual unrepaired DNA damage may be critical determinants in the processes leading to cell death.
Although base damage may have serious consequence for a cell, low levels of base damage are difficult to measure by physical or chemical means (Paterson, 1978), by contrast, DNA strand breaks can be detected with great sensitivity by many methods. Pulsed field gel electrophoresis (PFGE) Whitaker, et al., (1995), constant field gel electrophoresis. (CFGE) Dikomey et al., 1997) and neutral filter elution (Zaffaroni et al., 1994) have shown a correlation between radiosensitivity and residual unrepaired DNA double-strand breaks.

A common thing in these methods is that they measure DNA double strand breaks and hence are sensitive for 


\section{Elmaghraby, T}

measurement high dose of irradiation. Fluorometric analysis of DNA unwinding (FADU) in an alkaline medium method was used to measure DNA damage at low doses (1-10 Gy). The methodology is based on the principle that the rate of DNA unwinding is a sensitive measure of strand breaks (Kohn et al., 1976).

\section{Materials and Methods:}

Cercopithecus aethiops (African green monkey, vero), Homo sapiens hepatocellular carcinoma (HePG2) were grown in Eagle medium supplemented with $10 \%$ foetal bovine serum (FBS) human blood was cultured in 199 medium. All cultures were kept at $37^{\circ} \mathrm{C}$ in a humidified atmosphere of $95 \%$ and $5 \% \mathrm{CO}_{2}$.

\section{Irradiation:}

Exponentially growing cells were irradiated with $1-5 \mathrm{~Gy}^{60} \mathrm{CO}$-irradiation at $1.45 \mathrm{~Gy}-\mathrm{min}^{-1}$ at Middle Eastern Regional Radioisotope Center for the Arab Countries. For the determination of DNA damage, cell suspensions were irradiated on ice.

\section{dNTPs treatment:}

Every cell type was divided into two groups after irradiation the first group was supplemented with dNTPs (Sigma) at concentration of $5 \times 10^{-5} \mathrm{M}$ from $0-30$ minutes after $\gamma$-radiation and the second one was not supplement.

\section{Cell survival:}

HePG2 and Vero cell line, colony assay (Wilson, 1992) was performed on monolayers, growing in log phase. Cells were seeded in triplicate at appropriate cell numbers in a $25-\mathrm{Cm}^{2}$ flasks to yield $\sim 100$ surviving colonies. After 4 hours when cells were attached, they were exposed to graded doses of cobalt irradiation after 5-6 days cultures were fixed [in acetic acid: methanol: $\mathrm{H}_{2} \mathrm{O}(1: 1: 8)$, stained in $0.01 \%$ amino black] and colonies containing 50100 cells were counted, survival fractions were fitted to the linear-quadratic equation, mean inactivation dose ( $\overline{\mathrm{D}}$ ) was derived as described by KiLtie et al.,(1997).

Fluorometric analysis, of DNA
unwinding (FADU):
The DNA unwinding was measured
by FADU methods according to
Birnboim et al., (1981) and Ogiu et al.,
(1992) modified by Roos, et al., (2000).

\section{Results:}

\section{Irradiation induced DNA damage:}

The dose response curve for DNA damage induction expressed as percent remaining double strand DNA, is shown for the 30 minutes repair time initial damage (Figure1), 24 hours repair time without dNTPs supplement (Figure2) and 24 hour repair time with dNTPs (Figure.3).

It was apparent that the increase of the irradiation dose gaves rise to an increase of damaged DNA. This implies that an increase of the irradiation precipitates DNA strand breaks. This relation is very clear especially at the initial damage. The percent of initial DNA damages are $90 \%, 78 \%$ and $92 \%$ in lymphocytes HepG2 and Vero, respectively. This revealed that DNA in HepG2 cells had most of the DNA damage, while DNA in Vero cells suffered less DNA damage. In 30 minutes repair time, the slopes of the sensitive HepG2 cell line and the resistant Vero cell line were -4.78 and 1.39 respectively, indicating that the initial DNA damage differs between 2 cell lines by a factor of 3.5 (Table.1). The same picture was revealed in 24 hours repair time without DNA supplement (Figure 2). The dNTPs have clear role in diminish the DNA damage especially in the HePG2 cells (Figure.3).

\section{2- Clonogenic survival:}

Survival data for resistant cell line Vero revealed that $\overline{\mathrm{D}}$ was 2.5 and for sensitive cell line HepG2, $\overline{\mathrm{D}}$ was 1.12 showing a >2 fold difference in radiosensitivity (Figure 4 and Table2) 
Table (1): Result of fluorometric analysis of DNA unwinding (FADU)

\begin{tabular}{|l|c|c|c|c|c|c|}
\hline & \multicolumn{3}{|c|}{ Slope } & \multicolumn{3}{c|}{ Double DNA at 5Gy (\%) } \\
\cline { 2 - 6 } & $\begin{array}{c}\text { Initial } \\
\text { damage }\end{array}$ & $\begin{array}{c}\text { Residual } \\
\text { damage }\end{array}$ & $\begin{array}{c}\text { Residual } \\
\text { damage } \\
\text { with DNTPs }\end{array}$ & $\begin{array}{c}\text { Initial } \\
\text { damage }\end{array}$ & $\begin{array}{c}\text { Residual } \\
\text { damage }\end{array}$ & $\begin{array}{c}\text { Residual } \\
\text { damage } \\
\text { with DNTPs }\end{array}$ \\
\hline Lymphocytes & $-1.62 \pm 0.21$ & $-0.58 \pm 0.04$ & $-0.38 \pm 0.05$ & 90 & 93 & 95 \\
\hline HepG2 & $-4.78 \pm 0.97$ & $-3.64 \pm 0.73$ & $-3.12 \pm 0.68$ & 78 & 84 & 89 \\
\hline Vero & $-1.39 \pm 0.11$ & $-0.41 \pm 0.06$ & $-0.24 \pm 0.03$ & 92 & 96 & 97 \\
\hline
\end{tabular}

Table (2): Radiosensitivty parameters of Vero and HepG2 cell lines.

\begin{tabular}{|c|c|c|}
\hline Cell line & SF2 & $\overline{\mathbf{D}}$ \\
\hline Vero & $\mathbf{0 . 5 2}$ & $\mathbf{2 . 5 0}$ \\
\hline HePG2 & $\mathbf{0 . 1 5}$ & 1.12 \\
\hline
\end{tabular}

SF2 surviving fraction after $\gamma$-irradiation, $\overline{\mathrm{D}}$ mean inactivation dose

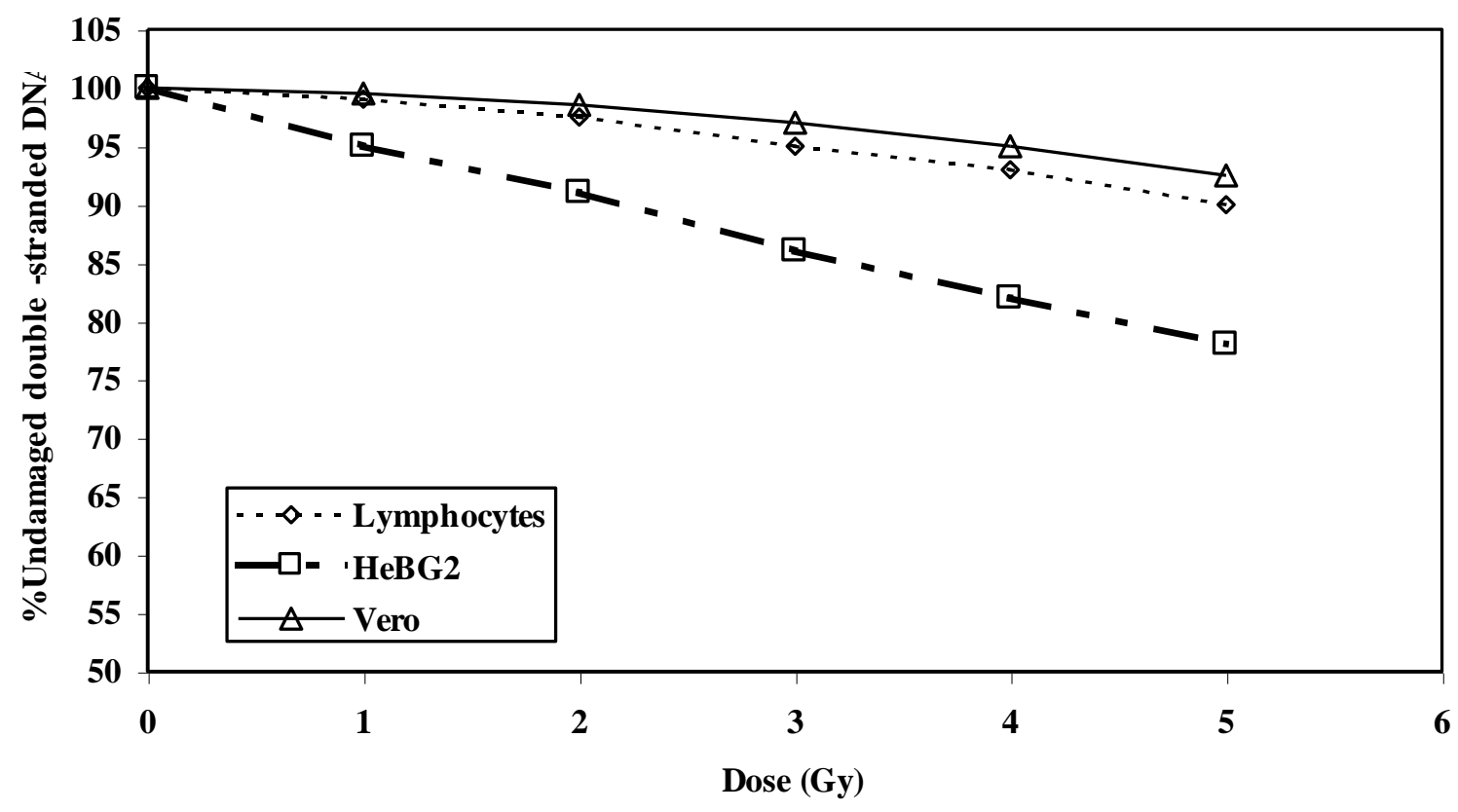

Figure (1) : Total amount of DNA damage (initial damage) as measured by the fluorometric analysis of DNA unwindinig Lymphocytes,HepG2 and Vero. 
Elmaghraby, $\mathbf{T}$

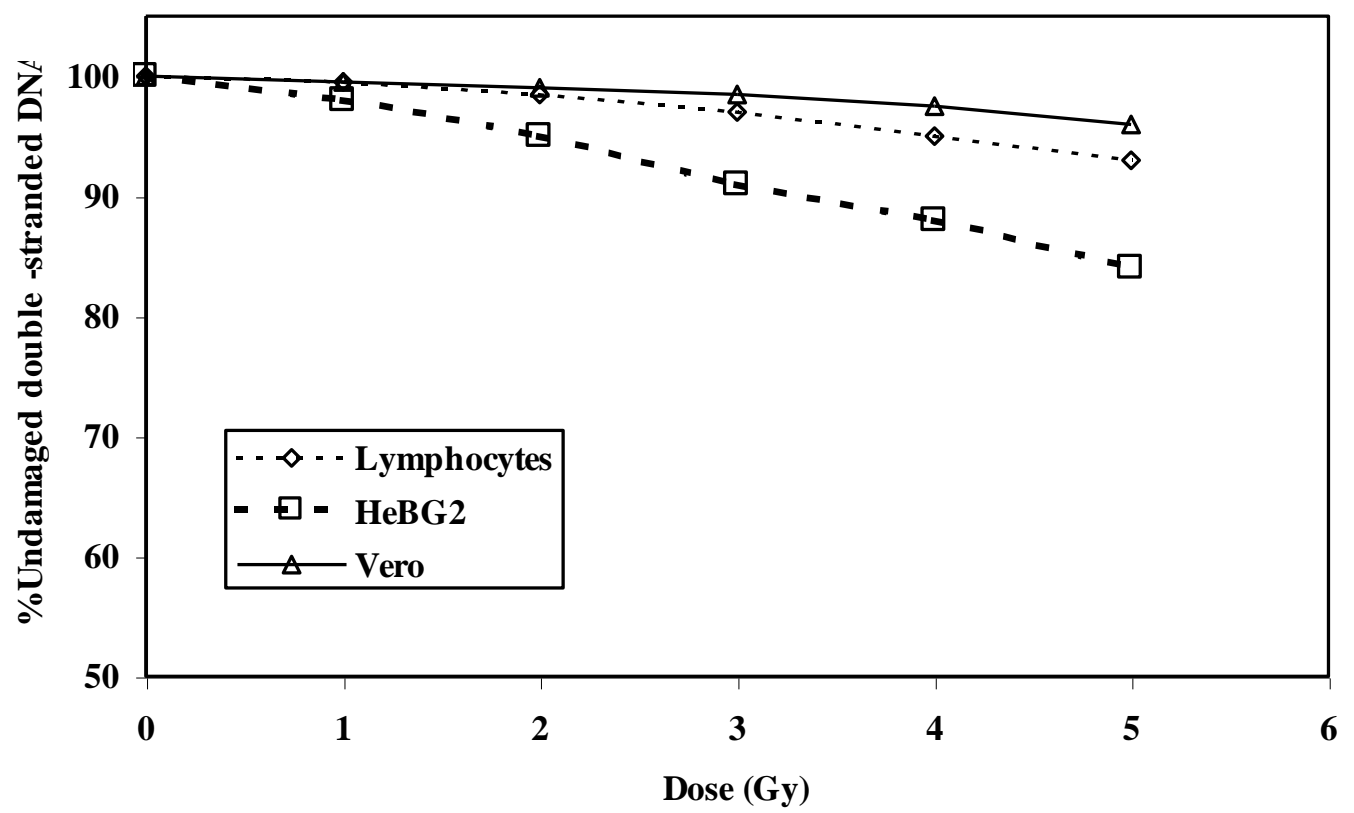

Figure (2) : DNA damage remaining after 24-hours repair as measured by the fluorometric analysis of DNA unwinding method.

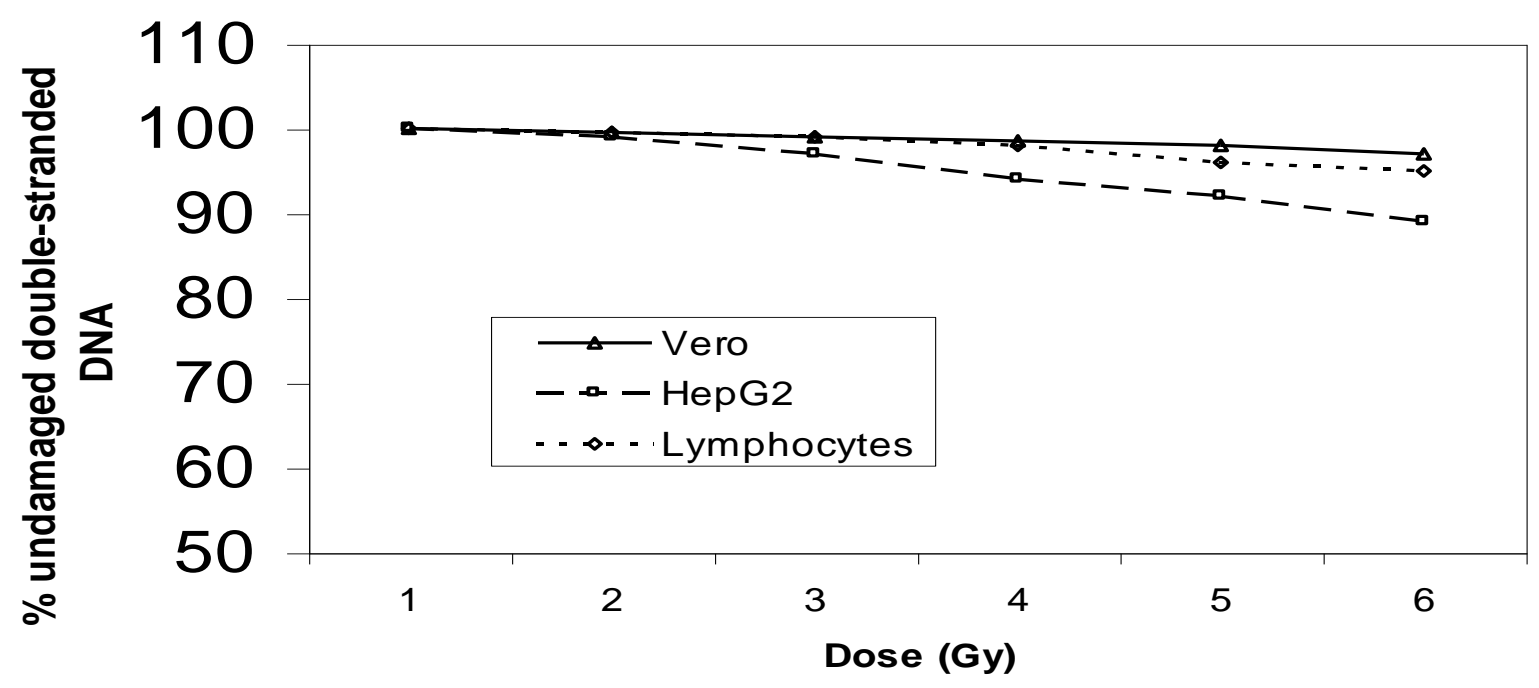

Figure (3): DNA damage remaining after 24 hours repair with DNTPs as measured by fluorometric analysis of DNA unwinding method. 


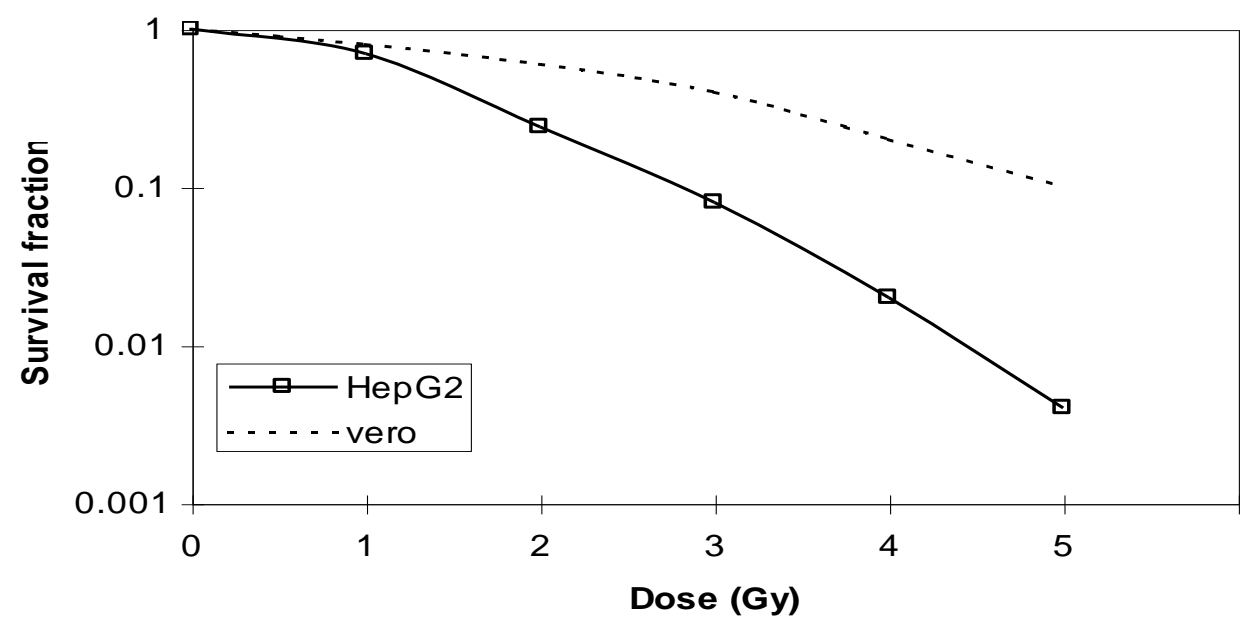

Figure (4): Survival curves for HepG2 and Vero cell lines.

\section{Discussion:}

Our results reveals that an increase of the irradiation dose precipitates an increase of DNA strand breaks. A number of intrinsic mutagens induce structural damage in cellular DNA (Gros, et al., 2002). Ionizing radiation produces highly cytotoxic double-strand breaks or local multiply damaged sites (Ward, 1988). DNA damage was inferred from the remaining double-stranded DNA after unwinding in alkali. For a given dose, radiosensitive cell line (HePG2) shows a low level of residual intact DNA while radioresistant cell line (Vero) show a high level of residual intact DNA (Figure1). Moreover, survival data for Vero $(\overline{\mathrm{D}}=2.5)$ and HePG2 ( $\overline{\mathrm{D}}=1.12)$ indicate that cell survival and hence radiosensitivity is a reflection of the initial DNA damage (Figure 4). This agree with the results of Roos, et al., (2000). Factors that could influence and regulate the initial DNA damage are chromatin loop size (Heng , et al., 1996) and chromatin compaction (Chapman, et al., 1999).

Indeed analysis of chromatin compaction by transmission electron microscopy in both normal CHO-K1 hamster cell line and the repair deficient mutants $\mathrm{xr} 55$ cells has come to the conclusion that cells with the highest level of compacted chromatin in interphase show the highest radiosensitivity ( Chapman, et al., 1999)

Some experiments using high dose irradiation and measuring the induced double-strand breaks by Pulsed field gel electrophoresis (PFGE) and constant-field gel electrophoresis (CFGE) methods have also come to the conclusion that radiosensitivity is correlated with the initial DNA double strand breaks (Whitaker, et al., 1995).

Other studies using similar techniques and high doses demonstrate that radiosensitivity does not correlate with initially induced DNA double-strand breaks (Dikomey, et al., 1997) but with the residual unrepaired DNA double-strand breaks. The strength of these data (Dikomey, et al., 1997) is that they rest upon measurement of DNA double-strand breaks. However, a weakness of this apporoach is that it requires high doses beyond the clinical range. Recent studies indicate the sensitivity of DNA assay (Usol'tsev, et al., 2000, Baumstark-Khan, et al., 2000 and Usol'tsev, et al., 2002). The first line of defence against ROS (reactive oxygen species) that were generated by ionizing radiation is inactivation of superoxide by superoxide dismutase. A second line of defence, incorporation of 


\section{Elmaghraby, T}

damaged bases into DNA is prevented by enzymes that hydrolyse oxidised dNTPs (8oxod GTP) to the corresponding deoxynucleoside 5'-monophosphate (dNMP). The third line of defense is the repair of oxidative damage in DNA by an intricate network of DNA repair mechanisms. These mechanism include base excision repair (BER), nucleotide excision repair (NER) and the nucleotide incision repair (NIR), (Gros, et al., 2002). The present results revealed that supplementing the cell lines with dNTPs mixture has a clear role in diminishing the DNA damage caused by radiation. Hennig, et al., ( 1996) showed that injection of mice with dNTPs improved repair in cells with low pool size and reverse lethal radiation damage. Deoxyribonucleosides reverse the lethal damage in the BALB/c line, but not nearly as strongly as original undamaged DNA. Moreover, dNTPs injected 1 day prior to $\gamma$ irradiation provides some protection against the lethal effects of radiation, Hennig, et al., (1996). DNA excision repair requires the insertion of bases into gap in the DNA which arise during the removal of damaged sites from the chromatin. Moreover, the same author reported that the number of bases required is dependent on the amount of damage and patch size of repair in response to particular type of damage, Snyder, (1984).

Because FADU is simple, rapid and sensitive, it may have application in several areas related to human health. Basically DNA strand breaks can be monitored in any mammalian cell type that can be prepared as a homogenous suspension. For example, if an agent which is known to produce strand breaks is to be used in chemotherapy, then the in vivo or in vitro response of cells from a particular individual to that agent could be monitored. Information about cell sensitivity could be helpful in selecting the most appropriate drug and its dosage. Another application is for the development of short-term test systems, which could detect DNA-damaging environmental agents, Mclean, et al., 1981. On conclusion, FADU can be used easily to choose a suitable treatment (Radiation or drug) and its dosage according to measurements of DNA damage on selective malignant tissues. Moreover, using dNTPs mixture can reduce the side effect of these treatment.

\section{Acknowledgements}

The author thank professor Mohammed ahmed ali professor of virology in National Center for Research for the cell lines and Dr. Amer Abd El Azim in ElMehlla Chest hospital for his help and guidance.

\section{References:}

1. Baumstark-Khan, C., Hentschel, U., Nikandrova, Y., Krug, J. and Hormeck, G. (2000), Fluorometric analysis of DNA unwinding (FADU) as a method for detecting repair-induced DNA strand breaks in UV-irradiated mammalian cells. Photochem Photobiol., 72 (4): 477-84,.

2. Birnboim, H. and Jevcak, J. J. (1981), Fluorometric method for rapid detection of DNA strand breaks in human white blood cells produced by low doses of radiation. Cancer Research, 41, 1889-1892.

3. Chapman, J. D., Stobbe, C. C., Gales, T., Das, I. J., Zellmer, D. L., Biade, S. and Matsumoto, Y. (1999), Condensed chromatin and cell inactivation by single-hit kinetics., Radiation Research, 151, 433$441 .$.

4. Dikomey, P. E., Dahm-Daphi, J., Bremmer, I., Martensen, R. and Kaina, R., and Kaina, B. (1997), Correlation between cellular radiosensitivity and non-repaired double strand breaks studied in nine mammalian cell lines. International Journal of Radiation Biology, 73, 269-278..

5. Gros, L., Sapabeav, M. K. and Faval, J. (2002), Enzymology of the repair of free radicals-induced DNA damage. Oncogene, 16; 21 (58) 8905-25,.

6. Heng, H. H., Chamberlain, J. W., Shi, X. M., Spyropoulos, B., Taui, L. C., and Moens, P. B. (1996), Regulation of meiotic chromatin loop size by chromosomal position. Proceeding of the National Academy of Science, USA, 93, 2795-2800,.

7. Henning, U .G, Wang, Q., Gee ,N.H. and von Borstel, R.C. (1996), Protection and repair of $\gamma$-radiation-induced lesions in mice with DNA or deoxyribonucleoside treatments. Mutation Research , 350,247254. 


\section{Protective effect of deoxynucleotide.........}

8. Kiltie, E., Orton, C. J., Ryan, A. J., Roberts, S. A., Marples, B., Davidson, S. E., Hunter, R. D., Margison, G. P., West, C. M. and Hendry, J. H. (1997), A correlation between residual DNA double -strand breaks and clonogenic measurements of radiosensitivity in fibroblasts from periradiotherapy cervix cancer patients , International Journal of Radiation Oncology Biology Physis, 39, 1137-1144,.

9. Kohn, K. W., Erickson, L. C., Ewrig, R. A. G. and Friedman, C. A. (1976), Fractionation of DNA from mammalian cells by alkaline elution, Biochemistry, 15, 4629-4637,

10. Mclean, J. R. Mc Williams, R. S., Kapian, J. G. and Birnbom, H. C. (1981), Rogress in Mentation Research, Vol.1 Amsterdam: Elsvier/ North-Holland Biomedical press.

11. Ogiu, T., Fukami, H. and Nishimur, $M$. (1992), DNA strand breaks and death of thymocytes induced by n-methyl-nitrosourea, Journal of cancer Research and Clinical Oncology, 118, 2329..

12. Patreson, M . C. (1978 ), Use of purified lesion-recognizing enzymes to monitor DNA repair in vivo. Adv. Radiat. Biol.,7:1-53,.

13. Roos, W. P., Binder, A. and Bohm, L. (2000),Determination of the initial DNA damage and residual DNA damage remaining after 12 hours of repair in eleven cell lines at low doses of irradiation, Int. J. Radiation-Biol., 76, 11, 1993-1500.

14. Snyder, R. D,(1984), The role of deoxyribonucleotide triphosphate pools in the inhibition of DNA -excision repair and replication of human cells by hydroxyurea, Mutation Res.,131,163-172.
15. Steel, G. G. and Peacock, J. H. (1989), Why are some human tumors more radiosensitive than others ? Radiotherapy and oncelogy, 15, 63-72 Synder, R. D., Mutation Res., 200, 193-199. (1988).

16. Usol'tsev, MV., Durmev, A. D. and Seredenin, S. B. (2000), The use of the fluorimetric method for studying DNA integrity exemplified by an assessment of dioxidine genotoxicity. Ekspklin Franakol., 63 (2): 60-2,.

17. Usol tsev, MV., Kapkova, I., Durnev, A. D. and Seredenim, S. B. (2002), Mutagen effects in various organs and tissues of rats studied by fluorometric analysis. Eksp Klin Farmakol., 65 (4): 47-50,.

18. Ward, J . F., Prog. (1988), DNA damage produced by ionizing radiation in mammalin cells: identities, mechanisms of formation and repairability Nucleic Acid Res.,35,95-125,.

19. Whitaker, S. J., Ung, Y. C. and Mcmillan, T. J. (1995), DNA double -strand breaks induction and rejoining as determinants of human tumour cell radiosensitivity. A pulsed-field gel electrophoresis study. International Journal of Radiation Biology, 67, 7-18.

20. Wilson, P. (1992), Cytotoxicity and viability assays. In R. I. Freshney (ed.), Animal cell cultureL A practical Approach, $2^{\text {nd }}$ and (Oxford: IRL, Press). 263-303,.

21. Zaffaroni, N.; Orlandi, L., Killa, R., Berzatto, A., Rofstad, E. K. and Silvestrini, R. (1994), DNA double strand-break repair and radiation response in human tumour primary cultures. Internationa ournal of Radiation Biology, 66, 279-285. 
التأثير الوقائى للنيوكلوتيدات على تكسير الحمض النووى فى الخلايا الثيية المختلفة بعد تعرضها لأشعة جاميا

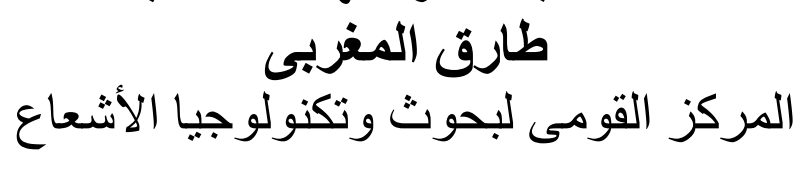

الحمض الديوكسى ريبوزى يعتبر أكثر المناطق الحرجـة فى الخليـة المستهدفة

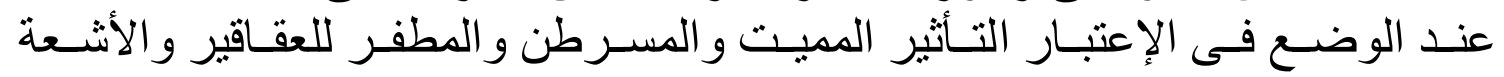
و الكيماويات البيئية.

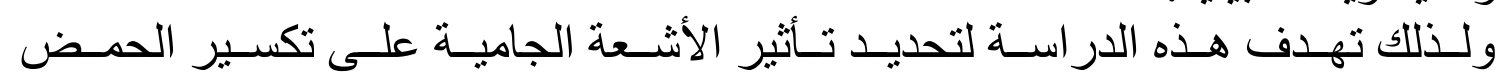

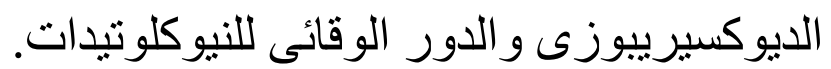

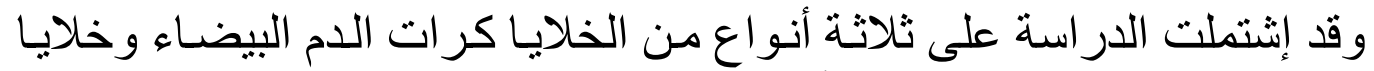

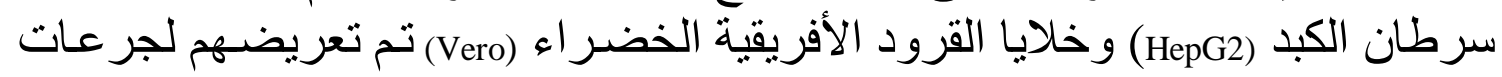
ن

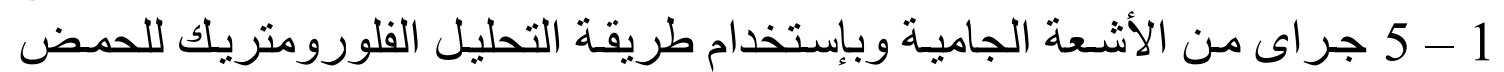

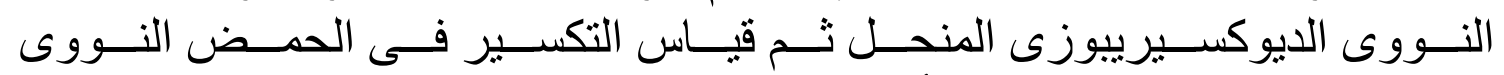

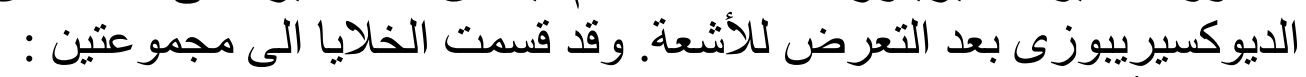

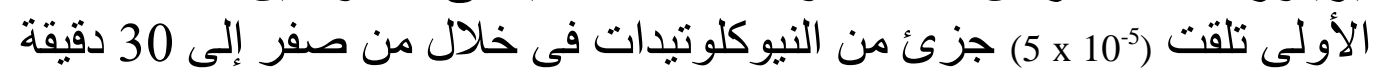

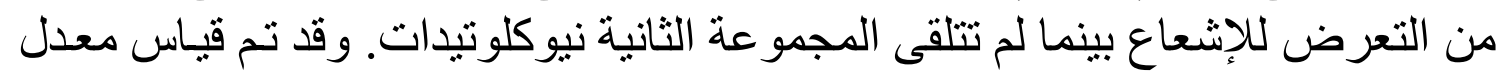

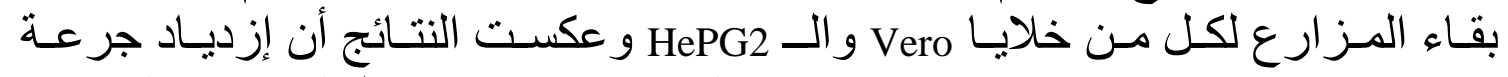

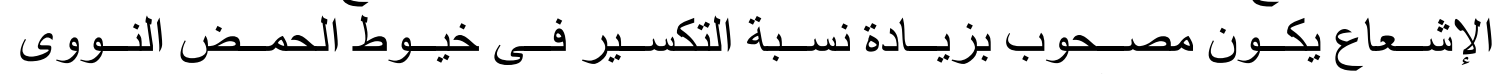

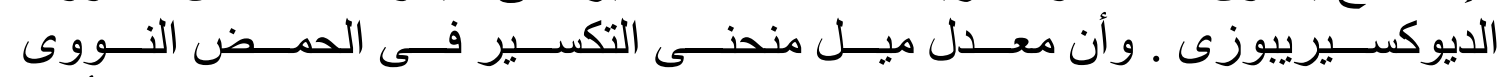

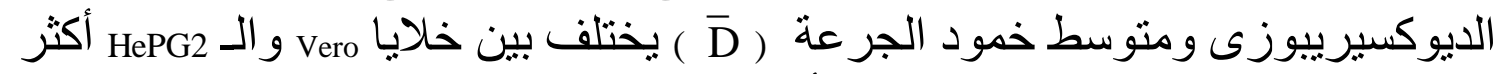

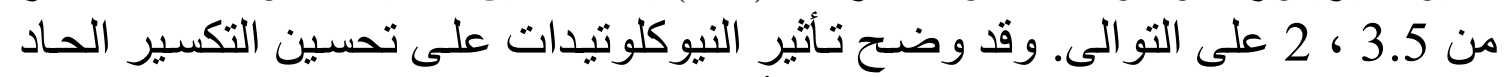

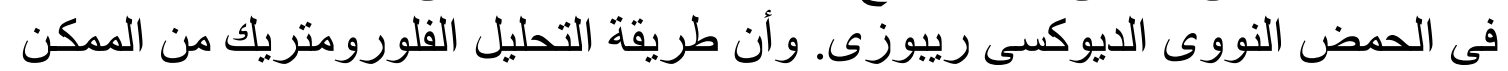

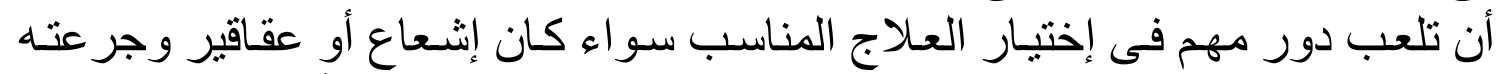

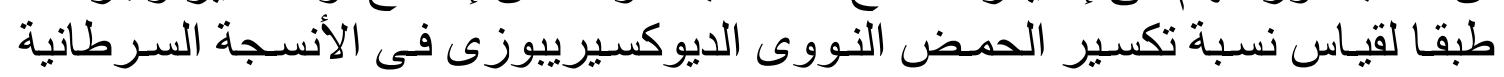

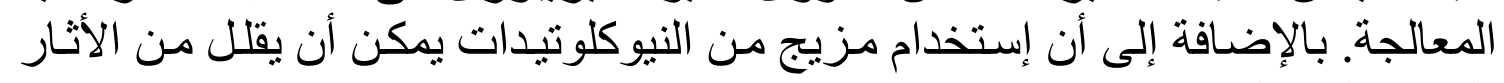

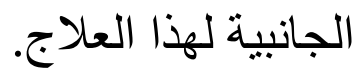

